\title{
SAT1 wt Allele
}

National Cancer Institute

\section{Source}

National Cancer Institute. SAT1 wt Allele. NCI Thesaurus. Code C51343.

Human SAT 1 wild-type allele is located in the vicinity of Xp22.1 and is approximately $21 \mathrm{~kb}$ in length. This allele, which encodes diamine acetyltransferase 1 protein, plays a role in the regulation of polyamine intracellular concentration and polyamine transport out of cells. An allelic variant of the SAT gene is associated with keratosis follicularis spinulosa decalvans. 